NGTT Deel 54, Nommers 3 \& 4, September en Desember 2013

Conradie, Ernst

University of the Western Cape

\title{
On Jesus Christ as Mediator of creation
}

\begin{abstract}
This contribution offers reflection on two of Dirkie Smit's conversation partners, namely Herman Bavinck and Karl Barth. It notes that both are deeply Trinitarian theologians, but also that such a Trinitarian approach has to address a number of underlying difficulties with respect to the work of the Father, son and Holy Spirit. On this basis the distinct positions of Bavinck and Barth on the relationship between Christ and creation is explored. Both would confirm that Jesus Christ is the "Mediator of creation" but adopt different approaches in this regard. Such underlying differences are explored and highlighted with the help of GC Berkouwer's attempt to mediate between these approaches. The essay concludes with the observation that Smit's emphasis on the centrality of the resurrection may suggest a critical correction to discourse on "Christ and creation".
\end{abstract}

\section{ON LONG-DISTANCE CONVERSATION PARTNERS}

One of the striking features of South African Reformed theology is the way in which scholars have adopted long-standing, long-distance conversation partners. The aim of adopting such conversation partners is not merely to contribute to scholarship on, for example, Augustine, Luther, Calvin, Barth or Bonhoeffer. Instead, the life and work of these long-distance conversation partners are employed as lenses or as sets of conceptual tools through which the challenges of the South African context may be addressed.

This feature may well be an ambiguous function of our colonial legacy, since the conversation partners typically come from the Netherlands and Germany, while a few others come from England and the United States of America. One's dominant conversation partners are indicated not only in the titles of articles or books, but in the bibliographies and footnotes of such contributions. Not surprisingly, adopting such conversation partners is highly contested. Amidst the church's struggle against apartheid the names of "Kuyper" and "Barth" suggested a world of difference. In liberation theology the term "primary interlocutors" is used to challenge theologies orientated exclusively towards European concerns. Many have emphasised the need for doing theology in conversation with the poor and the oppressed (not "for" them), instead of with the "cultured despisers of religion", albeit that conceptual tools derived from Europe (for example, from Marx) are still adopted for that purpose. Either way, the footnotes of theological works published in South Africa reveal worlds of difference in terms of conversation partners and theological orientation.

These observations are relevant with respect to Dirkie Smit's life and work in several ways. First, he has clearly also adopted such long-term conversation partners (see below). Second, compared to Smit's teachers of theology he had demonstrated an astonishing ability to widen the range of conversation partners beyond a narrow Dutch or German orientation without discarding them. I have heard him say that South African theologians read more widely (taking note of more diverse sources) than is the case in most, if not all, other contexts. Third, his fondness of footnotes is indicative of his ability to read and integrate a gigantic corpus of 
NGTT: Oopbron - http://ngtt.journals.ac.za

literature. This is typically the nature of his contributions, namely to offer an overview of entire theological discourses while restraining himself in offering constructive contributions. In this way Smit offers heuristic service to those around him by helping to place the positions of others (including generous references to his own students and colleagues) within a map of the terrain. Finally, his work is always highly contextual. Smit responds to invitations by seeking to take the questions that are raised seriously, in order to listen to the articulated needs and to help uncover the underlying assumptions. His oeuvre is, therefore, distinctly South African even when engaged in surveys of North Atlantic literature.

In this contribution I will explore Smit's choice of dominant conversation partners. It is no secret that he time and again returns to John Calvin and especially to Karl Barth for guidance. It is also not difficult to gauge what attracts him to Barth. First, Barth was able to respond to the theological crises associated with World War I and II. Smit sensed that this was the kind of theology that was needed in order to respond to challenges posed by apartheid and apartheid theology, and later by globalization. Second, Barth's confessional approach to theological reflection helped to guide him in his life-time work as co-author and main interpreter of the Belhar Confession. As my colleague Christo Lombard once astutely observed in a course on South African theologies offered at UWC, Dirkie Smit's work may be captured in two words: "embodied confession" - as a form of situated discourse. Third, Barth's deeply Trinitarian approach to theological reflection satisfied his desire to remain true to Nicene Christianity in his own work. Fourth, Barth's ability to keep theological reflection in balance with ethical responsibility, ecclesial praxis and a cheerful sense of piety remains crucial. Here was a theologian who maintained the primacy of the church as one of the "publics" for theological reflection, while also being deeply engaged in various spheres of society and the academy. Finally, Smit recognised through Willie Jonker, his teacher, supervisor, and father-in-law, how liberating Barth's theology could be for South African Reformed theology that was trapped in a sterile form of Reformed orthodoxy, if not fundamentalism. Dirkie Smit's postgraduate theses (his earliest writings) focused on three very different conversation partners, namely Jürgen Habermas (on dialogue), Herman Bavinck (on truth and verification) and Karl Rahner (on theology as anthropology). In my own recent work on the relationship between creation and salvation as acts of God, I have returned to my theological roots after shunning that earlier by exploring contemporary contributions to ecotheology. More specifically, I returned to the work of Abraham Kuyper and Herman Bavinck, remembering a comment from Willie Jonker that his own theological work remained very much in line with those two figures who helped to reform Dutch Reformed theology. I found especially in Bavinck's position on nature and grace and in his notion of "re-creatio" (herschepping), insights that are highly attractive if one is searching for a theology that could do justice to both God's acts of creation and of salvation - which is rather elusive, to say the least. I rediscovered Bavinck's oeuvre with a certain freshness, amazed at the emphasis (compared to Barth) that he placed on affirming science, art, philosophy, society and nature. This was not quite the Bavinck I read earlier - which was through the lens of Berkouwer and Noordmans - or in the form of the textbooks by Willie Jonker, Jaap Durand and Flip Theron, my mentors in systematic theology.

This brought me to a thought experiment. What if Dirkie Smit, given his early work on and lasting respect for Herman Bavinck (1856-1921), opted for the latter instead of for Karl Barth (1886-1968) as a dominant conversation partner? What difference would that have made? There is no need here to explore such a speculative question. However, it is important to assess what may be at stake in selecting one's conversation partners. In the rest of this contribution I will, therefore, explore one of the core differences between Bavinck and Barth, namely about 
NGTT Deel 54, Nommers $3 \& 4$, September en Desember 2013

the relationship between Christ and creation. In order to do that I need to preface that with a few comments on the need for a Trinitarian approach to theology - which Bavinck and Barth certainly shared.

\section{ON THE DIFFICULTIES IN ADOPTING A TRINITARIAN APPROACH}

In a famous essay on The Necessity of a Trinitarian Theology, Arnold van Ruler observes that "[s]imply recognizing the necessity of a Trinitarian theology does not mean that one succeeds in the project" (1989:1). He adds that he has not found such a theology in the entire Christian theological tradition, suggests that Calvin approached that ideal most closely, and admits that he is not able to offer anything approximating that. This comment may sound odd given the renaissance of Trinitarian theology in the past century and the astonishing flourishing of books on the doctrine of the Trinity over the last three decades.

However, a "fully Trinitarian" theology remains more elusive than a mere affirmation of its significance may suggest. Why is that the case? The key does not necessarily lie in revisiting classic Trinitarian debates and distinctions or in delving into a form of inner-Trinitarian mysticism based on the "social analogy". The key lies in seeing how the Trinity governs the very core of the Christian confession and forms its doxological conclusion - rather than a point of departure for an entire theological system. Yet such a doxological conclusion is undermined by a number of factors. For the sake of brevity, let me mention three core issues.

First, while the filioque controversy may be regarded as a highly technical theological dispute, the underlying issue of the relationship between the Christ and the Holy Spirit is of immense pastoral significance. One may argue that it continues to divide Christians in South Africa those in mainline churches who suggest that the Spirit works through Christ (the church, the Word and the sacraments) and those who suggest that the Spirit "blows in different directions" (see the essays in volume 79 of Scriptura under the title Wither Does the Wind Blow?). One example (outlined in an unpublished paper by Dirkie Smit at the annual meeting of the Theological Society of South Africa in 2002) is the differences in ecumenical theology between those who adopt a Christological orientation (for example, Geoffrey Wainwright) and those who call for a pneumatological reorientation in the name of a fully Trinitarian approach (for example, Konrad Raiser).

Second, it is far more difficult to do justice to both creation and salvation than it may appear at first sight. Typically the one is subsumed under the other or under a third category. The most acute formulation of the issue at stake is perhaps by Mercy Amba Oduyoye (2000:75): Is the God of our redemption the same God of our creation? The same underlying problem emerges in many issues in ecclesial praxis, for example, on church and society, Christianity and culture, homosexuality, faith and science, and the relationship between Christianity and other religions. Again this matter divides Christianity deeply as the challenges posed by Marcion, the Gnostics, the Manicheans and various forms of dualism indicate. How is the material related to the spiritual and how can one do justice to that which is material, bodily and earthly? How does the work of Jesus Christ relate to that of the Father? The criticisms of "Christomonism" and a "binitarian" theology often raised against Barth reveal something of the underlying tensions. Regin Prenter (1946:161-182) accused Barth of "creation docetism" while Gustaf Wingren (in Vander Goot 1981:145) went so far as to suggest that Barth influenced many to regard the first article of the Christian creed as a Nazi principle. Although these criticisms may well be refuted by Barth scholar- ship, they do suggest that a Trinitarian theology needs to go beyond a mere affirmation of relatedness to explore the nature of the relationship in all its complexity. 
NGTT: Oopbron - http://ngtt.journals.ac.za

Bavinck's rhetoric here is striking:

The God of creation and of the Old Testament is not lower than the God of re-creation, than the Father of Christ, than the God of the new covenant. Christ, the mediator of the new covenant is also he by whom God created all things. And the Holy Spirit who is the author of regeneration and sanctification is the same as he who in the beginning hovered over the waters and adorned the heavens. Creation and re-creation, therefore cannot be contrasted in terms of being lower and higher. They are both good and pure - splendid works of the one Triune God (2008:436).

Third, the relationship between God the Father and the Holy Spirit poses another set of issues. Perhaps this becomes most evident in Christian responses to religious diversity. This forms a test case for an affirmation of the doctrine of the Trinity in ecclesial praxis, also and especially in the African context. For one group of Christians the only way to engage with people of other faiths is to acknowledge that "God has many names" and that knowing God as the Father of Jesus Christ is only one such name. Thus faith in the triune God is reduced to faith in God the Father on the basis of some form of subordianism, the link between the immanent Trinity and the economic Trinity is discarded and God's revelation is clouded. The God who is revealed in Jesus Christ is different from the actual One behind the mask. Ironically, the Spirit (or a vague sense of spirituality) provides the generic category to place different notions of the transcendent, of Ultimate Reality alongside each other, thus compromising their ultimacy. While no Trinitarian theologian would put the matter in such crude terms, the challenges for ecclesial praxis remain undeniable in a world characterised by a "clash of civilisations" and religion-infused conflict. How could faith in the triune God plausibly guide Christians in such a context? How can the Trinitarian mystery be protected doxologically? Indeed where can such a Trinitarian theology be found?

\section{ON BAVINCK AND BARTH, NATURE AND GRACE}

Given these comments on Trinitarian theology, comparing Bavinck with Barth is quite illuminating. Through his studies of Reformed theology, Barth knew Bavinck's Reformed Dogmatics and occasionally referred to it affirmatively. One example is a reference to Bavinck's discussion of the incomprehensibility of God (Barth CD 2.1, 1957:186). For the early Barth, God can only be known as the unknown God. In Jesus Christ as well, God becomes accessible to us only through the impossibility that the eternal Logos can become flesh, through the veiling of the cross. Indeed, Barth and Bavinck have much in common, including the Reformed tradition in which they stand, their soteriological focus, their strong Christological orientation and a consistently Trinitarian approach to theological reflection.

The clearest difference between them may well be in terms of political economy rather than theology. Bavinck was a member of the Anti-Revolutionary party, Barth a staunch socialist. Both parties took up the cause of the kleine luyden, but differed on the "revolution" that was required. Barth responded to the crisis posed by the liberal legitimation of German nationalism and instigated something of a theological revolution. Bavinck was a lifelong critic of liberalism too, but compared to Barth his social ethics seems to be more establishment-orientated.

Theological differences emerge when Barth and Bavinck's respective views on nature and grace are considered. Barth's critique of natural theology is well documented. Bavinck's affirmation of the necessity of general revelation would raise Barth's deepest suspicions. 
NGTT Deel 54, Nommers 3\& 4, September en Desember 2013

The relationship between nature and grace is a central theme in Bavinck's whole oeuvre. In a translated extract from his doctoral thesis entitled Nature and grace in Herman Bavinck, Jan Veenhof (2006:16) says: "It is the central theme that recurs in numberless variations, the refrain that is unceasingly repeated, the leitmotif that we hear everywhere." In the introduction to the English translation of Reformed Dogmatics, Volume 1, John Bolt (2003:18) suggests that the Trinitarian expression that "graces restores natures" shapes Bavinck's entire theology. The cosmic scope of Bavinck's understanding of the Christian faith is indeed unmistakable in his own summary: "that the creation of God the Father, ruined by sin, is restored in the death of the Son of God and recreated by the grace of the Holy Spirit into a kingdom of God" (2003:112). Bavinck's soteriology may be captured under the rubric of "re-creation" (herschepping) and entails a consistent affirmation of God's creation as creatura - and thus of the spheres of culture, art, science and reason. Salvation in Jesus Christ is not an aim in itself, but to restore nature, to allow God's creation to flourish again. God's grace is indeed threefold: the original blessing of God's creation as indeed "very good", common grace and special grace (cf. Veenhof 1968:409). Only special grace functions soteriologically. For Bavinck, the deepest intention of Reformed theology is, therefore, a rehabilitation of the first article of the creed by affirming the value, indeed the eschatological significance, of that which is natural.

All of this is rather different in tone from Barth's critique of natural theology. Barth would scarcely have called for a theological appreciation of that which is "natural". For Barth, the emphasis is thus not on the created order (creatura) as the work of God (which, of course, he also affirmed), but on the God who created. In his famous discussion of the "lesser lights" he acknowledges that the world contains its own mysteries (alongside its mere existence, rhythms, contrariety, regularity and freedom - which Barth also examines), but this remains the world's mystery, not God's mystery or even that of the revelation of God (1961:149). That God the Father is the one who created can only be discovered through the teaching of Jesus Christ on his Father. Colin Gunton (1992:94) suggests that there is a "critical consensus" on the weakness of Barth's position on this particular point, namely his ability to do justice to the created order itself.

Barth's own mature position was that God's work of creation is the construction of the necessary space for the history of the covenant of grace. Thus creation forms the "external ground" for the establishment of the covenant. Because of God's election, the world is created and also sustained (cf. CD 3.1, 1958:44). Creation as creatura is thus understood in terms of covenant and creation as act of God in terms of election.

\section{On Christ and CREATION}

Underlying these differences one may detect deeper differences with regard to the way in which the relationship between Christ and creation is understood. Both Bavinck and Barth would acknowledge that God's act (decree) of creation forms a necessary presupposition for the possibility of incarnation. Moreover, both would emphasise the role of Christ in mediating the act of creation: "through him all things were made". Creation is not merely the work of the Father but also of the Son and the Spirit. However, for Bavinck this mediating role belongs to the Son eternally begotten from the Father (the logos asarkos). By contrast, Barth insists that this could only be known if one allocates this mediating role to Jesus Christ incarnate (the logos ensarkos) - leading to a "strongly immanentist theology" (Gunton 1992:95). This allows Barth to suggest that anthropology and creation theology may be built upon God's election in Christ. Jesus is not only the Mediator of reconciliation but the most authentic, the original 
NGTT: Oopbron - http://ngtt.journals.ac.za

human being (Runia 1955:104). From here further theological differences emerge: Did God create the world for the sake of the incarnation or did God become incarnate for the sake of creation? Or is the purpose of the incarnation to redirect creation to its original destiny which was from the beginning in and through Christ (Gunton 1992:94)? Bavinck (2004:424) comments on this long before the time of Barth:

This notion then automatically leads to a doctrine of incarnation apart from sin. The world as such is profane; creation is not really a divine work. For God to be able to create and for the world and mankind to be pleasing to him, he must view them in Christ. God could only have willed the world in Christ and for Christ. It is only in Christ as the head and central individual of the human race that we can be pleasing to God. In this view the incarnation is necessary for the revelation and communication of God, and the Godman is the supreme goal of creation. Ultimately, this train of thought culminates in the theory that the creation was necessary for God himself ... This Gnosticism can only be fundamentally overcome when all dualism between God and the world is cut off at the root. Creation as a work of God is not inferior to re-creation; nature is not of a lower order than grace.

Another way of framing the issue at stake relates to the relationship between revelation and incarnation. Both Bavinck and Barth insist that God's revelation is primarily, if not exclusively, found on the basis of the incarnation. Such a virtual identification of incarnation and revelation is understandable given the uniqueness of God's revelation in Jesus Christ. However, as Berkouwer (1955:93) observes, the exclusivity of God's revelation cannot simply be derived from the exclusivity of salvation in Christ.

Bavinck could even teach the identity of revelation and incarnation since Christ is the very centre of God's revelation (cf. Veenhof 1968:321-327). He says:"Revelation and incarnation stand and fall with each other. The incarnation is the completed, sustainable, eternalised revelation" (quoted in Veenhof 1968:408) [my translation - EMC]. However, for Bavinck this identity encompasses both special revelation and general revelation. The incarnation epitomises and concludes the history of God's special revelation. Special revelation is nothing but preparation for the incarnation. Special revelation assumes general revelation though (for a more detailed discussion, see Conradie 2011:55-62). The incarnation also epitomises God's general revelation in the work of creation. Already in the creation of human beings God becomes incarnate in the created image of God (cf. Bavinck RD 1, 2003:344). Nature itself is God's incarnated word! As Veenhof (1968:412) observes, this begs the question whether Bavinck was able to do justice to the radical newness of God's gracious salvation in Jesus Christ - so that special revelation tends to be degraded towards a special instantiation of general revelation.

For Barth, the very distinction between general and special revelation was problematic. It cannot but prepare the way for natural theology. In Barth's famous polemics against Brunner on the status of natural theology, he denied the need for any "point of contact" between Christ and our context, between the proclamation of the gospel and our hearing the gospel. There is no need for such a point of contact because the bridge is not provided by the human capacity to understand the gospel but by God's revelation in Jesus Christ. Since Jesus Christ embodied God's presence amongst us, there is no need to find any other point of contact (Barth 2002:121). The infinite gulf between God and the world, therefore, cannot be bridged by humans and need not be, as it has been crossed already - in Jesus Christ. The word (of forgiveness) creates its own point of contact and does not rely on any such point of contact in 
NGTT Deel 54, Nommers $3 \& 4$, September en Desember 2013

human beings. There is no need to find vague traces of God's presence elsewhere in "general revelation"; if indeed they can be found. Theological reflection on Christ and on the world (creation) has to be kept together; the logic of first offering an exposition of the problem (fallen creation) to which Christ provides the "answer" (redemption) has to be resisted.

Instead, Barth insists that our knowledge of God is not derived from any previous knowledge of other lords or lordships; it is a consequence of God's revelation in Christ alone. He also insists that there is no analogy on the basis of which the nature and being of God as Creator is accessible to us:

If we do know about God as the Creator, it is neither wholly nor partially because we have prior knowledge of something which resembles creation. It is only because it has been given to us by God's revelation to know Him, and what we previously thought we knew about originators and causes is contested and converted and transformed (Barth CD II.1, 1957:77).

We cannot move from knowledge of creation to knowledge of the Creator. It is not as if the first article of the Christian creed provides common ground with other religious traditions, only to be divided by the second article. The first article is also a matter of faith in Christ (cf. also Runia 1955:108).

One may argue that Barth's critique against natural theology was, in fact, aimed at an anthropocentric interpretation of the first article of the Christian creed that was so typical of liberal theology in the wake of Kant's critiques: where human self-understanding forms the key to the knowledge of God. Ironically, Barth has often been criticised from the perspective of ecotheology for a similar anthropocentrism, but then of the second article of the creed, namely a reduction of the scope of salvation to the encounter between human beings and God in Jesus Christ (cf. Santmire 1985; Thiemann 1981:124).

Yet another way of framing the underlying differences relates to the order of addressing the relationship between creation and salvation. Bavinck maintained the historical order where God's work of creation is followed by the fall and then by God's work of re-creation, thus privileging an infralapsarian position with regard to the divine counsel. By contrast, Barth not only affirmed a noetic priority for Christ over creation. He also affirmed an ontic priority: creation was necessary for the sake of Jesus Christ, that is, for the sake of God's covenant in Christ. Creation may be the first of God's opera ad extra, but does not have the same primacy in God's eternal counsel. Creation is a prefiguration of reconciliation; it has no independent purpose but to make reconciliation possible (cf. Runia 1955:107-117; Veenhof 1968:411).

While Bavinck maintained the historical order, Barth rejected a chronological "phase theory" of creation-fall-redemption as historical stages in order to stress the unity of God's work. For Bavinck, Christology is the central theme of dogmatics, but not the starting point (cf. RD II, 2006:274); for Barth it is both the central point and the starting point. Runia (1955:120) describes this as the main difference between Bavinck and Barth. Barth dubs the historical order as "double bookkeeping", thinking in phases, first in terms of creation and then in terms of redemption. He inverts this historical sequence by arguing from Christ to Adam, from God's election in Jesus Christ to the election of humanity. His sequence is, therefore, one moving from election to reconciliation. In the name of the unity of God's work Barth thus avoided any independent interest in creation or in the orders of creation (cf. also Berkouwer 1956:52-88, 215-261). However, such a soteriological interpretation of creation renders creation dependent 
NGTT: Oopbron - http://ngtt.journals.ac.za

upon salvation. It begs the question what creation is to be saved from. Can the inherent goodness of that which is natural, material, bodily and earthly then still be affirmed? Or is creation itself an act of salvation from the shadow side of creation, if not from Das Nichtige?

This suggests that one can distinguish between the twin dangers of monism and dualism (Berkouwer 1956:254). Kuyper has been rightly criticised for compartmentalising creation and salvation, allowing for an independent interest in creation to the point that the orders of creation also structured the nature of salvation (and of grace). By contrast, Barth has been criticised by Van Ruler (1947:120) for a monism of grace, for fusing creation and salvation so that the act of creation itself becomes salvific and grace becomes God's only work (see also Runia 1955:115). Such a tidy unity of creation and salvation comes at the cost of much speculation (cf. Runia 1955:117; Veenhof 1968:412).

\section{On Berkouwer's way of mediating Between Bavinck and Barth}

Berkouwer's considerable oeuvre may be understood as a constant engagement with Barth's ongoing work, on the one hand, and Roman Catholic theology on the other hand. He wrote several books on Barth's theology in which he seems to become less and less critical of Barth's position. His own theology was deeply rooted in Bavinck's renewal of Reformed theology. It may, therefore, be interesting to trace this engagement to see how he mediated between these two figures (see also Conradie 2011:96-98).

Berkouwer's early review of Barth's theology in Geloof en Openbaring in de Nieuwere Duitsche Theologie (Faith and Revelation in the Newer German theology) (1932) is already quite interesting. Here he argues that Barth's radical emphasis on the subjectivity of God and his rejection of any form of continuity between God and humanity leads to the affirmation that God can only be known by Godself. Berkouwer wonders whether Barth can account for the impact of salvation on God's own creation. Does any focus on that which is creaturely necessarily jeopardise the sovereignty of God (1932:212)? There is a need, Berkouwer says, for a correlation between revelation and faith in which faith is not seen as something that leaves the created reality untouched. Berkouwer criticises Barth's actualistic understanding of faith on the basis of his conviction that faith is to be understood within the tension between creation and re-creation. For Berkouwer creation may be distinguished from God, has an integrity of its own, yet remains dependent upon God. God's revelation touches creation in the form of faith. The underlying problem, Berkouwer argues, is Barth's emphasis on act instead of being. He asks whether one can still speak of the real existence of creation (creatura) or whether this would necessarily jeopardise an actualistic understanding of God's work (Berkouwer 1932:212; cf. also Brinkman 1983:35-42). Brinkman captures Berkouwer's early critique of Barth in the following way:

According to Berkouwer, for Barth there could be no possibility that God's grace would transform the relationships that were created. Grace does not actually restore life but stands outside of it. Faith remains alien to life (Brinkman 1983:66) [my translation - EMC].

Here Berkouwer is clearly in continuity with Kuyper and Bavinck, his neo-Calvinist teachers.

Berkouwer also criticised Barth's ethics on this basis. Can Barth's radical emphasis on God's work maintain God's sovereignty in every sphere of life? How does it really touch society? Barth's theology does lead to protest against Nazism, but such protest is focused on matters of confession within the church (against the German Christians) and is necessarily vague in 
NGTT Deel 54, Nommers $3 \& 4$, September en Desember 2013

making recommendations in society (Brinkman 1983:53-54).

In his book Karl Barth en de Kinderdoop (Karl Barth and Infant Baptism) (1947), Berkouwer argues that a historical sequence may help to prevent theological speculation. Where the unity of creation and re-creation is emphasised, there may be the temptation to devaluate the role of history. Berkouwer comments: "To qualify the 'very good' Christologically would lead to the relationship between original good creation and fall becoming vague and shallow" (Berkouwer 1947:121) [my translation - EMC]. What is especially crucial is to maintain the fall as an event which entered the world in history in the form of rebellion against God. Where this is not acknowledged (albeit perhaps not in terms of a singular historical event), it may have repercussions for an affirmation of the goodness and value of the created order and for an understanding of re-creation. Berkouwer argues that Barth's position on infant baptism has everything to do with his understanding of the relation between creation and salvation. He concludes, in my translation, that

[i]t has been typical of reformed theology that it ... maintained the real and irreversible historical sequence with no less emphasis. This alone allowed it to make the break in created reality evident and to recognise the guilt and responsibility following that break (Berkouwer 1947:128, see also Brinkman 1983:83).

In The Triumph of Grace in the Theology of Karl Barth, Berkouwer returns to this point. Drawing on Regin Prenter, he suggests that the manner in which redemption and creation cross each other, imperils the significance and decisiveness of history:

[Barth's] conception leaves the impression that everything has already been done, all the decisions have been taken, so that one can hardly say that the historical fall and the historical reconciliation are at issue, but only the revelation of redemption in history, the revelation of the definitive Yes of God's grace. There is no question of a "step-wise", one after the other, of creation and redemption. The whole of creation fundamentally rests in redemption (Berkouwer 1956:250) [italics in original].

And:

The eschatological triumph [over the forces of chaos] will be no more than the revelation of this fact. Only one mandate remains for man to fulfil: to see through the appearance of things and not to fear (Berkouwer 1956:260).

Berkouwer observes that Barth's supralapsarianism here draws him into emphasising the unity of God's work more than its distinctness. However, Berkouwer suggests that the unity of God's work and the rejection of a historicising of the works of God (as if God could be surprised by historical developments, as if God's actions depend upon human actions) are not necessarily contrary to such a step-wise sequence. These comments suggest that there is a need to avoid both a compartmentalising of the various aspects of God's work (for which Kuyper has been criticised - cf. Van der Kooi 1999:99) and a fusion of God's work (for which Berkouwer criticises Barth).

What Barth legitimately objects to is the way in which liberal theology has gradually denied guilt and the need for reconciliation. In this way a "double book- keeping" could emerge which paved the way for the "single bookkeeping" of human reason (Berkouwer 1956:259). Although Berkouwer acknowledges Barth's critique in this regard, he is evidently more attracted to 
NGTT: Oopbron - http://ngtt.journals.ac.za

an infralapsarian emphasis on creation, fall and redemption as discrete historical events (as accounted for in the divine decrees). His continuity with Bavinck is evident here. On this basis there is a need to do theology and to confront evil from within the midst of history, living with anxiety due to the uncertainties of the future and where the decision of faith is still of significance - instead of the proclamation of the triumph of grace as something eternal in God and only revealed in history (Berkouwer 1956:260-261). Berkouwer's questions highlight the danger of a noetic reduction of the meaning of history and of salvation itself. The human predicament is not merely a lack of knowledge - which can be addressed by revelation, but the struggle in the midst of history against the tangible manifestations of evil.

Inversely, Barth also tends to render an ontological status to evil and suffering through his notion of the shadow side of creation. For Berkouwer, this tends to conflate sin with the human predicament of finitude. He is clearly hesitant to allow for suffering in God's good creation. He therefore asks Barth:

Can death be regarded as belonging to human nature as it came from the hand of God, or is death an alien, destructive power which has penetrated the good creation and is contrary to human nature? ... Is death, although standing under the power of God, anything else than evil only? (Berkouwer 1956:154).

If death is embedded in creation, then the eschaton would have to overcome an inherent problem in creation. Berkouwer's concern is, therefore, that the fusion of creation and salvation inversely leads to too much emphasis on the eschatological discontinuity of God's works.

\section{ON INCARNATION AND RESURRECTION}

There can be little doubt about Berkouwer's influence on South African Reformed theology through his supervision of many doctoral candidates, including Willie Jonker. It is another matter what such South African Reformed theologians heard and learnt from Berkouwer. Did they find a path leading to Bavinck's consistent affirmation of science, reason, art and culture? Did they consider his remarkably early critique of apartheid theology? Were they enticed towards his increasing appreciation of Barth? Did they follow his existentialist narrowing of Bavinck's Reformed theology? Did they learn from his broad engagements and from the mildness of his judgements?

Whatever the answers to these questions may be, it is at least clear that Dirkie Smit's work cannot be neatly captured under any of these rubrics. He was clearly excited by the avenue leading towards Barth, but through his engagement with so many other conversation partners from different contexts he gained an ecumenical range that is truly astonishing.

Given the theme of "Christ and creation" considered here, one of the most obvious features of Smit's own constructive contributions is his desire to re-orientate theological reflection along confessional lines towards the witnesses to the resurrection of Jesus Christ. Following Barth, he has emphasised the centrality of the resurrection to an understanding of the Christian faith, the gospel, the church and ministry consistently. This clearly suggests a correction to discourse on "Christ and creation" that all too often employs the incarnation as a point of departure. If, then, the resurrection may be used as a point of departure to explore the relationship between "Christ and creation", this would require further reflection on the bodily resurrection and indeed, following Calvin, on the bodily ascension. As Gunton (1992:61) notes, 
NGTT Deel 54, Nommers $3 \& 4$, September en Desember 2013

if the transformation associated with the resurrection is not related to that which is bodily, this effectively restricts the possibility of Christ's resurrection transforming the whole of creation (what was not risen cannot be redeemed). This applies especially if, again following Barth, the resurrection is understood eschatologically. The material form in which God's revelation comes to us is crucial, if this revelation is to transform the material world to which it is addressed and where it is confessed. God's engagement with the world cannot be reduced to prophetic critique. The incarnation of the Word cannot be reduced to a word about the incarnate Word. The key clearly lies with considering the full spectrum of Christological symbols: incarnation, ministry, cross, resurrection, ascension, session and parousia. Indeed, the key lies in a fully Trinitarian theology, elusive as that may be. This is indeed Dirkie Smit's deepest theological intuition.

\section{BiBLIOGRAPHY}

Barth, K. 1957. Church Dogmatics II.1. Edinburgh: T\&T Clark.

Barth, K. 1958. Church Dogmatics III.1. Edinburgh: T\&T Clark.

Barth, K. 1961. Church Dogmatics IV.3.1. Edinburgh: T\&T Clark.

Barth, K. 2002 [1946]. No! An Answer to Emil Brunner. In Barth, K. and Brunner, E. Natural Theology. Eugene, OR: Wipf \& Stock, 67-128.

Bavinck, H. 2003. Reformed Dogmatics, Vol. 1: Prolegomena. Grand Rapids, MI: Baker Academic.

Bavinck, H. 2006. Reformed Dogmatics, Vol. 3: Sin and salvation in Christ. Grand Rapids, MI: Baker Academic.

Bavinck, H. 2008. Reformed Dogmatics, Vol. 4: Holy Spirit, Church, and New Creation. Grand Rapids, Ml: Baker Academic.

Berkouwer, G. C. 1932. Geloof en Openbaring in de Nieuwere Duitsche Theologie. (Faith and Revelation in the Newer German Theology.) Utrecht: Kemmink en Zoon.

Bolt, J. 2003. Introduction. In Bavinck, H., Reformed Dogmatics, Vol. 1: Prolegomena.

Berkouwer, G. C. 1947. Karl Barth en de Kinderdoop. (Karl Barth and Infant Baptism.) Kampen: Kok.

Berkouwer, G. C. 1955. General Revelation. Grand Rapids, MI: Eerdmans.

Berkouwer, G. C. 1956. The Triumph of Grace in the Theology of Karl Barth. Grand Rapids, MI: Eerdmans.

Brinkman, M. E. 1983. De Theologie van Karl Barth: Dynamiet of Dynamo voor Christelijk Handelen: De Politieke en Theologische Kontroverse tussen Nederlandse Barthianen and Neocalvinisten. (The Theology of Karl Barth: Dynamite or Dynamo for Christian Action: The Political and Theological Controversy between Dutch Barthians and Neocalvinists.) Baarn: Ten Have.

Conradie, E. M. (ed.). 2002. Whither Does the Wind Blow? South African Reflections on the Relationship between the Holy Spirit and Christ. Scriptura 79(1), 1-105.

Conradie, E. M. (ed.). 2011. Creation and Salvation: Dialogue on Abraham Kuyper's Legacy for Contemporary Ecotheology. Leiden: Brill.

Gunton, C. E. 1992. Christ and creation. Carlisle: Paternoster.

Oduyoye, M. A. 2000. Hearing and knowing: Theological Reflections on Christianity in Africa. Nairobi: Acton.

Prenter, R. 1946. Die Einheit von Schöpfung und Erlösung: Zur Schöpfungslehre Karl Barth. Theologische Zeitschrift 2(3), 161-182.

Runia, K. 1955. De Theologische Tijd bij Karl Barth. (Theological Time in Karl Barth.) Franeker: T. Wever.

Santmire, H. P. 1985. The Travail of Nature. Philadelphia, PA: Fortress.

Smit, D. J. 1976. Waarheid en Verifikasie by Herman Bavinck. (Truth and Verification in Herman Bavinck.) Unpublished licenciate thesis, Stellenbosch University.

Thiemann, R. F. 1981. Toward a Theology of Creation. A Response to Gustaf Wingren. In Vander Goot, H. (ed.), Creation and Method: Critical Essays on Christocentric Theology. Washington, DC: University of America Press, 119-36.

Van der Kooi, C. 1999. A Theology of Culture: A Critical Appraisal of Kuyper's Doctrine of Common Grace. In Van der Kooi, C. and De Bruijn, J. (eds.), Kuyper Reconsidered: Aspects of His Life and Work. 
NGTT: Oopbron - http://ngtt.journals.ac.za

Amsterdam: VU, 95-101.

Van Ruler, A. A. 1947. Droom en Gestalte. (Dream and Form.) Amsterdam: Holland.

Van Ruler, A. A. 1989. Calvinist Trinitarianism and Theocentric Politics: Essays Towards a Public Theology, Bolt, J. (ed.). Lampeter: Edwin Mellen.

Veenhof, J. 1968. Revelatie en Inspiratie: De Openabrings-en Schriftbeschouwing van Herman Bavinck in Vergelijking met die der Ethische Theologie. (Revelation and Inspiration: Herman Bavinck's View on Revelation and Scripture Compared to that of Ethical Theology.) Amsterdam: Buijten \& Schipperheijn.

Veenhof, J. 2006. Nature and Grace in Herman Bavinck, tr. Wolters, A. M. Sioux Center, IA: Dordt College.

\section{KEY WORDS}

Christology

Creation theology

GC Berkouwer

Herman Bavinck

Karl Barth

\section{TREFWOORDE}

Christologie

Skeppingsteologie

GC Berkouwer

Herman Bavinck

Karl Barth 